\title{
A képelemzés lehetőségei a konduktív pedagógiában
}

\section{Földesi RenÁtA}

Eötvös Loránd Tudományegyetem, Neveléstudományi Doktori Iskola

\begin{abstract}
Petö András a negyvenes, ötvenes, hatvanas években mást tudott a mozgássérült személyekröl és mást is közvetített róluk, mint kortársai. Folyamatosan és szisztematikusan dokumentálta és dokumentáltatta az intézetében folyó munkát, így számtalan fénykép, mozgókép őrzi a konduktív pedagógia elsö szakaszának emlékét. Vizuális örökségünk kutatása ugyan még épp, hogy elkezdödött, de látható, hogy a képi történetek segíthetnek a szakmánkról, annak lényegéröl való gondolkodásban. A konduktiv pedagógia képeit vizsgálva elmondható, hogy alapvetöen alkalmazható rá az ikonográfia-ikonológia módszere és a megfejtett jelentések, szimbólumok segitségével egyetlen fotó is képes lehet bemutatni akár egy teljes eszmerendszert, ha megfelelö háttértudásunk van az adott korról és annak kulturális-társadalmi jellegzetességeiről, illetve a konkrét kutatási téma tényanyagáról.
\end{abstract}

Kulcsszavak: gyermekkor, konduktív pedagógia, mozgássérült, képi források, ikonográfiaikonológia

A konduktív pedagógia immár hetvenéves múltra tekint vissza. A hét évtized távlata okán feltárható és feltárandó a múltja, fejlődéstörténete, hiszen mára jól láthatóak azok a fordulópontok, amelyektől változott, formálódott. Ezeknek az átalakulásoknak őrzik nyomait történeti forrásaink, amelyeket rendszereznünk kell önmagunk alaposabb megértéséért, esetleg más nézőpontból történő értelmezéséért abból a célból, hogy minél többet megtudjunk Pető professzor pedagógiai koncepciójáról.

Írásom történeti aspektusból közelít a konduktív pedagógiához, forrásként használva egy, a Pető Intézetben fellelhető, az oktató-nevelő munkához és a dokumentációhoz kapcsolódó fényképet. Tulajdonképpen előtanulmány egy komplex kutatáshoz, amelyben párhuzamba állított narratívák beszélik el a konduktív nevelés klasszikus korszakának történetét. Képsorozatok, neveltek és nevelők kortárs visszaemlékezései, tankönyvek, jegyzetek, korabeli sajtócikkek reflektálnak egymásra mint párhuzamos „valóságok”. Az elemzési folyamat végére azonban összefüzhetőek és segítségükkel megjeleníthetővé válik módszerünk, rendszerünk, egy árnyaltabb - teljesebb -, mélyebb értelmezése.
Jelen cikk kérdése az, hogy a konduktív pedagógia klasszikus (1945-1972) korszaka hogyan reprezentálódhat egy jellegzetes kép - történetben.

\section{Értelmezési keret}

A vizuális dokumentumok önmagukban nem hordoznak jelentést. Ahhoz, hogy megérthessük őket, szükség van egy kontextusra, melyben értelmet nyernek. Munkámban ezért elsőként megpróbálom bemutatni azokat a neveléstudományi területeket, melyek az elemzést vállaltan befolyásolták. Ezután térek rá az ikonográfia-ikonológia neveléstörténeti kutatásokban való alkalmazására, majd végül a képi történet kibontásával megmutatok egy lehetséges értelmezést. Mivel vizsgálódásom tárgya egy olyan kép, mely elkészítésének célja a konduktív pedagógia mindennapi gyakorlatának dokumentálása, nevelési folyamatának illusztrációja volt, értelmezési kereteként a gyermekkortöténet, az ikonográfial ikonológia és a konduktiv pedagógia jelölhető meg. Írásom ennek értelmében kísérlet egy mikroszintézisre. Egyrészt alulról építkezik, a mikroszint felől közelít, kiindulási pontja a 
gyermek, a gyermek életvilága. Fél évszázad távlatából tekint vissza egy karakteres intézményi környezet által formált gyermeklétre, ehhez egy „tipikus” képi forrást hívva segítségül.

\section{Gyermekkortörténet}

A gyermekkortörténettel foglalkozó kutatók munkái betekintést engednek többek között abba az évtizedek óta zajló, a neveléstudományt érintő folyamatba, melynek eredményeképpen ma már elfogadható, hogy nem kell történelem felettiként egyetlen tudásformát kitüntetni, normaként tekinteni. Kinek a tudása érvényes például a gyermekre nézve? A tudományé, a gyermeké, a szülőké a pedagógusoké? Vagy a különböző narratívák együtt érvényesek?

A történeti diskurzusokba mára szintén bekerült a „lehet-e beszélni univerzális, mindenkire érvényes gyermekkorról vagy elfogadható, hogy a gyermekkor, mint az emberélet egyik életszakasza az adott kor társadalmi, gazdasági, természeti viszonyaitól is függ" megközelítés. A tudományos párbeszéd részét képző másik fontos terület a diszkontinuitás-kontinuitás kérdése. A téma kutatói arra keresik a választ, hogy az egyes történelmi korokban hogyan alakul a gyermekekhez, illetve általában a gyermekléthez való viszony, létezik-e a polgárosodás kezdete előtt jól körülírható gyermekkorfogalom, illetve felfedezhetőek-e hasonló vonások a különböző történelmi korszakokban jellemző gyermekfelfogások között. Szintén érdekes lehet a gyermekkorokról való tudás, az arról való gondolkodás kérdése is.

Minden kornak, társadalomnak, politikai rendszernek - mely sürü, strukturált kapcsolatrendszer, tele függőségi viszonnyal - megvan a maga alkotta gyermekszemlélete és az erről való tudása. Ez a tudás generációkon átnyúló, ugyanakkor folyton változó képződmény, melyet az emberek egymást követő nemzedékei konstruálnak. A generációs tudás-átadás tanulással, a tapasztalatok tudás formájában történő továbbadásával valósul meg (Karácsony, 1995). Az tehát, hogy az adott kor, az adott jelen mit tud a gyermeklétről, magába foglalja mindazt, a már elmúlt, leírt, megélt tapasztalatot, mely az aktuális jelenben, aktuális helyen hozzáférhető. S minderre folyamatosan reflektál a jelen, kortárs tapasztalat-együttes is. E gondolat mentén haladva az adott gyermekkor értelmezésben, melyet többnyire jellemez az elégedetlen, feszültségekkel teli, inkonzisztens állapot, benne van a kritika is a kor gyermekfelfogására nézve, amely majd tovább alakítja, konstruálja a következő generáció gyermekről, gyermekkorról kialakuló tudását. Ennek alapján lehet a gyermekkorokról alkotott tudást is folyamatos mozgásként értelmezni, a múlt, jelen és jövő tükrében. $\mathrm{S}$ ha nemcsak a statikusan meglévő jelent látjuk, mikor az adott kor gyermeklétére tekintünk, feltételezhetjük, hogy az általunk használt tudás a fent leírtak értelmében egy szintézis eredménye. Benne foglaltatnak a hagyományaink, tapasztalataink és a jövőre irányuló vágyunk és kísérleteink a jobbításra. Minden korszak azonban csak a maga szintézisét végezheti el, az adott korban meglévő tudásszerkezetnek megfelelően.

A modern kor végével eltűnt a szebb jövőbe, a fejlődésbe vetett hit és ez vonatkoztatható a gyermekkorral, ifjúkorral kapcsolatos meglátásokra is. Háborúk, népirtások, erőszakkal „megoldott” konfliktusok sora járult hozzá a megdönthetetlennek tartott értékek eróziójához és ezzel összefüggésben a gyermekkor nyugati civilizáció által konstruált formájának alakváltozásához. A körülöttünk lévő világ gyorsan változik, nem úgy azok a szervezetek, amelyek az előző, modern korszakot legitimizálták intézményi szinten. Lassabban képes változni a család és vele együtt a szülői reakciók, és még lassabban változik az iskola. Nő a feszültség, hiszen a jelenkor újabb és újabb kihívások elé állítja a gyermeknevelés érintettjeit. A gyermekkor több vonatkozásban összecsúszik a felnőttkorral (Vajda, 1997; Winn, 1990), a gyermek-felnőtt élethelyzetek egyre hasonlóbbak (teljesítményelv, szórakozási lehetőségek és színterek), a gyermek-felnőtt küllem sem válik el élesen, a kommunikációs környezet robbanásszerűen változott 
az elmúlt tíz évben. Ezekről a jelenségekről és föleg hatásukról folyamatos a társadalmi és a szakmai diskurzus. Többen egyenesen a gyermekkor halálát vizionálják és egy „új középkor" eljövetelét hirdetik, mások túlzónak érzik ezt az apokaliptikus megközelítést (Buckingham, 2002).

A modern kor a gyermekkort sajátos életszakaszként fogadta el. Olyan intervallumként értelmezte, amelyben a gyermek a felnőtt életre, a felnőtt minőségre készül fel. A tudomány vallotta, hogy a gyermek sajátos, csak rá jellemző tulajdonságokkal, képességekkel és korlátokkal rendelkező lény. Ebben a megközelítésben rajzolódott ki az inkompetens, függő, éretlen gyermek (Aries, 1987) és vele szemben a kompetens, autonóm, érett felnőtt ellentétpár. Az elmélet alapjául szolgált az újabb és újabb racionális szemléletü, objektív igazságot kereső kutatások születésének, melyek eredményei hosszú időn át fenntartották az univerzális, minden gyermekre érvényes normatív fejlődési elvet.

A 20. század utolsó harmadától kezdődően aztán a tudományos diskurzusokban világszerte megfigyelhető volt a gyermekkorról való gondolkodás tekintetében az elégedetlenségüket kifejezők számának növekedése. A neveléstörténetben, a szociológiában és az antropológiában egyre erőteljesebben hívták fel a történeti és társadalmi aspektusokra a figyelmet (Pukánszky, 2001; Kluge, 2003), valamint arra, hogy a körülmény, közeg, melyben felnő az adott kor gyermeke, nem konstans, statikus, homogén, hanem rendkívül változó lehet. A huszadik század utolsó évtizedében megindult kutatások rávilágítanak, hogy nem lehet figyelmen kívül hagyni, hogy a gyermekek a különböző kultúrákba születésük által is meghatározottak, így fejlődésüknek az adott kultúrával összefüggő jellegzetességei vannak (Prout, 2004). A kutatói kitekintések nyomán - amelyek megkérdőjelezték a nyugati civilizáció mint egyedüli lehetséges vonatkoztatási pont használatát - az addig univerzálisnak tartott gyermekfogalom helyett a gyermeklétre adott helytől, időtől, társadalmi környezettől függő jelenségként is tekintettek. Biológiai éretlenség, hiányállapot helyett a gyermek- séget mint az emberi élet korai szakaszát írták le és a gyermekkor jellemzőit elkezdték újragondolni. Új kontextusokat fedeztek fel, és ezzel párhuzamosan elkezdték lebontani (dekonstrualizáció) az addig meglévő univerzalitás építőköveit. Ennek folyományaképpen ma gyermekkorokról, egymás mellett egyszerre létező értelmezésekről, egymásba fonódó gyermeknarratívákról beszélhetünk, és a gyermekkor alapvetően társadalmi konstrukcióként értelmezhető.

Megjelent az igény arra is, hogy a gyermekkorkutatásban helyet kapjanak a gyermekek mindennapjait megismerő kutatások. Ebben a szemléletben a gyermekek cselekvő aktorok és az ő jelentésmezőjük a lényeges. Egyértelművé tették, hogy a gyermekeket, gyermekkort nem lehet szociális kontextustól függetlenül vizsgálni és a gyermek nem egyszerűen környezetének öntudatlan terméke (Golnhofer és Szabolcs, 2005). Elkezdték feltárni, hogy milyen gyermeklétet vetít elénk a jelen társadalomban működő iskola, a család világa, a kortárs közösségek. Azt vizsgálták, hogy mindezek alakulásában, alakításában mennyiben és milyen módon vesznek részt maguk a gyerekek, hogyan érvényesül személyes kontrolljuk, önállóságuk, aktivitásuk. Életüknek különböző színterein hogyan rajzolódik ki a függőség-önállóság, szabályozás-ellenőrzés és kölcsönös függőség kérdése (Golnhofer és Szabolcs, 2005).

\section{Konduktív pedagógia}

Értelmezési keretem második eleme a konduktív pedagógia. Ahhoz, hogy az általam választott speciális kép értelmezéséhez legyen egy közös nevező, szükségesnek tartom bemutatni a konduktív nevelés rendszerét.

Pető András pályája orvosként indult, Bécsben több kórháznak, szanatóriumnak volt munkatársa, tuberkulózis, mozgásszervi megbetegedések, elmebetegségek, majd ortopédia a szakterülete. Az 1920-as, 30-as években gyógymódok egyesítésével kezdett kísérletezni, valamint ebben az időben került kapcsolatba a természetes gyógymódokkal, a homeopátiával, gyógynövénytannal, s ekkor 
ismerte meg a szervezet öngyógyító mechanizmusára építő eljárásokat. Ezek, a bécsi évek alatt szerzett tapasztalatok alapozták meg orvosi szempontból a későbbi konduktív nevelési rendszert.

Orvosként is alapvetésként tekintett az emberi képességek fejleszthetőségére. Tudta azonban azt is, hogy a központi idegrendszer sérülése következtében mozgássérültté vált emberek élete a korabeli hagyományos, orvosi eljárásokkal nem lesz befolyásolható. Ezért dolgozta ki újszerű, egységes „rehabilitációs" rendszerét, a konduktív pedagógiát, melynek gyökerei a 20. század első évtizedeiben kibontakozó, az egyéni és közösségi élet több szegmensére irányuló korabeli reformmozgalmakig nyúltak vissza, s törvényszerüen összefonódtak a korszak új nevelési törekvéseivel is, melyeket meghatároztak az újragondolt nevelési ideológiák, valamint az ezekből levezetett pedagógiai gyakorlatok. A 20. század első évtizedei nagy áttöréseket, újra-felfedezéseket hoztak a tudomány több területén. Pető András egyedisége, jelentősége abban állt, hogy rendszerében, módszerében orvosi, filozófiai, pszichológiai, pedagógiai eredmények korszerü elméleti ötvözetét hozta létre és annak mủködőképességét a gyakorlatban igazolta. Pető filozófiájának egyik alapgondolata az volt, hogy az ember nem szabdalható testrészekre, funkciókra, ezért egységes, összefüggő rendszerként kell értelmezni. Test, lélek, szellem jelenti az egészlegességet, $\mathrm{s}$ adja az ember lényegét, $\mathrm{s}$ ha bárhol zavart szenved ez az egység, az kihat a teljes rendszerre. Ez az egységszemlélet munkájának minden területét meghatározta. Ezt a felfogást, melynek alapjai megtalálhatók a keleti filozófiákban és gyógyításban, a reformmozgalmakban, a reformpedagógiákban, a korabeli magyar egészségügyi szervek elfogadhatatlannak, gyanúsnak tartották. A merev rendszer képtelen volt befogadni, elfogadni egy ennyire eltérő attitűdöt és gyakorlatot. Pető sokak számára meglepő módszere a folyamatos külső ellenállás ellenére idővel mégis fontos lehetőséggé vált a központi idegrendszeri sérültek és családjaik számára.
Gyógyítói/nevelői koncepciójának alapja az aktív napirend volt, amely a holisztikus emberszemléletből kiindulva, csoportos foglalkoztatási formában, szinte a teljes ébrenléti időszakot lefedve biztosított keretet a neveltek életéhez. Az általa alkalmazott, „technika”, a ritmikus intendálás (a mozgás szándéka és annak verbális megfogalmazása), a konduktorok (akkoriban kezelők) folyamatos jelenléte és az egyénre szabott célok, feladatok kiugró eredményeket hoztak a "képezhetetlenek” fejlesztésében.

A konduktív nevelési rendszer elnevezésben a nevelés kifejezés a folyamat célját határozza meg. Pető elképzelése szerint a helyes működés elérése érdekében nem valamely fogyatékosság változtatása, hanem a változásra képes ember segítése a cél. Ez a kognitív, az affektív és a kommunikatív szempontokat nagymértékben tekintetbe vevő nevelés útján lehetséges, mely elsődlegesen veszi figyelembe az emberi sajátosságokat, humánspecifikus tényezőket, melyek az érdeklődésre, kreativitásra épülő (ön)tevékenység szükséglete, a környezethez való kapcsolódás vagy tartozás szükséglete, a küzdőképesség és spontaneitás megléte. A konduktív szó a tanulás aktív formáját hangsúlyozza. A kondukció (rávezetés, rávezetődés) folytán belső célképzéshez vezet, melynek indikátora az élet-és élményszerü komplex tevékenységek kínálata. Az eredmény a szükséges belső szervezésmód kialakítása, az idegrendszer koordinációja.

A rendszer elnevezés a nevelési program strukturáltságát jelenti, mely egyszerre hálózatos, transzverzális és longitudinális. A rendszer a tevékenység struktúrájában az összefüggéseket biztosítja, egyszerre több interdependens tényezővel számol, s mint egységes kompozíció, tekintetbe veszi a környezettel való interakciókat is. A konduktív nevelési rendszer alapja az a vélemény, hogy az ember tanulása elsősorban újraépítés. Szemléletünkben a cselekvés, az alkotó mozgás nem az ismételtetésen keresztül, nem mechanikusan, passzív módon építődik be, hanem az aktuális tanulási helyzet megértésén és az azt követő aktivitáson alapul a nevelési folyamat minden apró szegmensében. Az 
A képelemzés lehetőségei a konduktív pedagógiában

ember meg akarja magát értetni és környezetét is meg kívánja érteni, ez a humán dimenzió minden emberi lény sajátja. Ezt a humán jelleget tartja a konduktív nevelési rendszer az ember birtokában lévő legfontosabb tanulási eszköznek. Ezért az egész nap olyan részekből épül fel, melyek egy jól megszerkesztett egészet képeznek, és olyan keretet adnak, amely lehetővé teszi, hogy a benne végzett cselekvések értelmet kapjanak azáltal, hogy az egész nap tartalmához kapcsolódnak az értés és értetés szolgálatában. A nap minden része vonatkozásban áll a nap többi részével; mindegyik rész a nap egészére is hat. A nevelési tervben az egyén legkisebb cselekvése is magában foglalja a program kontextusának emlékét, így egy kis probléma megoldása is olyan aktivitás, amely a teljes program keretében kapja meg igazi hangsúlyát. A konduktív nevelési rendszerben a nevelési folyamat metodikai egységben magában foglalja a mozgást, a beszédnevelést, az önellátást, a munkamozgások tanítását, az óvodai, az iskolai tanítást. A tér, az idő, a mozgás, az érzékelés, valamint a kommunikáció, amely a másikkal és a világgal összeköt. Mindez a konduktív pedagógiában egységes müködési területet képez. A figyelem, az érdeklödés felkeltését érdekes, újszerű tartalommal, élmény nyújtásával, a megoldandó feladat problémajellegével mozdítjuk elő. Az úgynevezett nem specifikus tényezők, mint a harmónia, az öröm, az esztétikum, a közérzet, a hangulati elemek és a különböző serkentő hatások is növelik a tanulók készenlétét. A konkrét cél, a perspektíva, a kihívás, a szociális siker és az egyén képességeinek pozitívumaira támaszkodás mind kognitív, mind érzelmi szempontból növeli a tanuló aktív részvételét a tanulási folyamatban (Petö, 1962).

\section{Ikonográfia/ikonológia}

Értelmezési keretem harmadik eleme az ikonográfia/ikonológia, mely valószínüleg nem válhatott volna napjainkra egyre hangsúlyosabbá Mitchell és Boehm (1998) képi turnje nélkül. Munkásságuk ráirányította a figyelmet arra a folyamatra, hogy a kép mint életün- ket folyamatosan alakító képződmény egyre nagyobb teret foglal el mindennapjainkban, gondolkodásunkban. A neveléstudomány képek felé nyitása is ehhez a folyamathoz köthető, hiszen vizsgálódásának tárgya az ember - mint nevelésügyi szereplő és életvilága - a tágabban vett pedagógiai tér, mind rendelkezik képi lenyomatokkal, reprezentánsokkal.

„Az, hogy az ikonológia/ikonográfia a neveléstörténet számára használatba vonható, meg sem kérdőjeleződött. Hiszen a történeti szemlélet az amúgy is történeti képzettséggel rendelkező kutatók számára evidenssé tette, hogy a társdiszciplínák látványos ikonológiai eredményei e téren is szavatolják a használhatóságot. Ugyanezt a tendenciát erősítette a művelődéstörténet, amely, amúgy is részeként látja a neveléstörténetet" (Géczi, 2012).

A fotó mint lehetséges kutatási eszköz és forrás az utóbbi években több szerzőnél (Sztompka, 2009; Pilarczyk és Mietzner, 2010) is megjelent, módszertanuk a pedagógiáról való gondolkodásban is hasznosnak mutatkozik. A nemzetközi kutatások mellett a hazai kutatók is sűrübben fordulnak az elmúlt évtizedekben a képi források felé, illetve az 1990-es évektől kezdődően a kutatásmódszertant tárgyaló munkákban is megjelenik mint lehetséges, innovatív módszer (Kelemen, 1997; Kéri, 2001; Németh és Szabolcs, 2001). A hazai kutatások a gyakorlatban is megmutatják a módszerben rejlő lehetőségeket, közülük mindenképpen iránymutató írásoknak tekintendők Géczi János, Kéri Katalin és Mikonya György munkái, melyek a kétezres évektől rendszeresen szerepelnek a neveléstudományi szaksajtóban. Géczi János (2008, 2010) több írásában tekinti át az ikonográfia/ikonológia helyzetét, illetve a sajtó - kép - neveléstörténet hármasán keresztül tágítja a metódus alkalmazási lehetőségeit. A gyermekkortörténettel foglalkozó kutatásokban is megjelenik az ikonográfia az ötvenes évek gyermekábrázolásához kapcsolódóan (Kéri, 2009), valamint a pedagógiai életképek vizsgálata szintén teret kap a kutatási témák között, erre Mikonya Györgynél (2006), Géczi Jánosnál (2010) is találunk példákat. Az elmúlt időszakot két nagyobb lélegzetü, 
interdiszciplináris módszertant alkalmazó munka is gazdagította, Endrödy-Nagy Orsolya (2015) és Somogyvári Lajos (2015) monográfiái. Előbbi a reneszánsz gyermekképét árnyalja tovább azáltal, hogy egy ez idáig nem kutatott időszakot elemez a 15-16. századi képzőművészeti alkotásain keresztül, utóbbi írás a hatvanas évek pedagógiájára reflektál, feltárva a korszak nevelési-oktatási viszonyait a korabeli sajtó képanyagán keresztül. Szintén a közelmúltban születtek Támba Renátó gyermekkor-történeti ikonográfia/ikonológia munkái, melyek a képzőművészetben megjelenő gyermekszemlélet mellett foglalkoznak osztálytermi fényképek elemzésével is (Támba, 2015). A fent említett kutatások bizonyítják, hogy az ikonográfia/ikonológia mint a neveléstudományban, azon belül a pedagógiatörténetben is használható módszer, nagyon sok lehetőséget rejt, segítségével verbalizálhatóvá válik a vizualitás. A képek leírásával, majd a szimbolikus tartalom, a mély struktúra felfejtésével, értelmezhető a kép, megmutatható egy lehetséges narratíva. A képek vizsgálatakor módszertan tekintetében is több lehetőség között választhatunk, kombinálhatjuk az eljárásokat, vagy tisztán alkalmazhatunk módszereket. Jelen írás az utóbbi mellett döntve, az Erwin Panofsky-féle elemzési eljárással próbálja szintről-szintre feltárni a képben rejlő rétegeket, majd eljutni a lényegi jelentéshez.

A Pető Intézetben tárolt képi források neveléstörténeti felhasználásának legfontosabb indoka, a képek létezése. Amennyiben a konduktív pedagógia kutatása a célunk, számba kell vennünk minden olyan forrást, legyen az kép, hanganyag, írott szöveg, amely a múltból ránk maradt, ami az archívumban és a Pető hagyatékban megtalálható. Az adott vagy adódó kutatási témák pedig kikényszerítik a források rendszerezését. Mivel a konduktív nevelésben a kezdetektől hangsúlyos szerep jutott a képi dokumentálásnak, jelen volt a mindennapokban, szerves része volt a képzésnek és a gyakorlati munkának, saját jogán tekinthető megkerülhetetlen kutatandó forrásnak. „A konduktor munkáját és munkájának eredményeit kritikusan felméri és ellenőrzi.
Megfigyeléseit rendszeresen rögzíti. Nagyon fontos a kezdeti állapot, majd a haladás és az eredmény kétségbevonhatatlan írásos, rajzos, fotós és filmes rögzítése, dokumentációja. A mozgáspedagógus megfigyeléseit szaktársaival állandóan megbeszéli és egyezteti, a kontinuitás nemcsak a nevelésre, hanem a megfigyelésre is vonatkozik" (Pető, 1962).

Pető és munkatársai tisztában voltak módszerük különcségével, különlegességével, ezért a mások számára érthetővé, követhetővé tétel, tulajdonképpen eredményességük igazolása létfontosságú volt számukra az ötvenes, hatvanas években. Különösen nehéz volt ez azért is, mert a tárgyalt időszakban tabunak számított a beteg, torz test megjelenítése a pedagógiai szaksajtóban. Alig találunk olyan írást, amely képi illusztrációt ad a fogyatékosság kérdéséhez. Kivétel ez alól a Család és Iskola szaklap, mely Török Sándor szerkesztősége alatt ugyan igen kis számban, de beemeli a sérült gyermeket ábrázoló képeket a pedagógiai diskurzusba (Török Sándor, Pető András barátjaként vállalta, hogy a lap hasábjain megjelentet fogyatékos gyermeket ábrázoló fotókat). A nyilvánossá tétel mellett fontos szempont volt az is, hogy az elkészített fényképek technikailag megfeleljenek a gyermekfényképezés gyakorlatában megfogalmazott kritériumoknak, ehhez nyújtott segítséget Reismann Mariann egy-egy gyermeket bemutató, mozdulatsort dokumentáló képsorozatokra vonatkozó munkája (Reismann, 1956).

Érdekes és izgalmas az a folyamat, mely során gyerekekről készített/készült képeken keresztül értelmezni lehet a fotók által közvetített gyermekéletet. Az elemzés előtt számos kérdés fogalmazódik meg. Lehet-e kiolvasni a hivatásos fényképész munkáiból a gyermekek életére nézve fontos információkat? Egyáltalán mi az, amit az intézeti léttel kapcsolatban megmutat a kép? Lesz-e olyan gondolat, mely a kép tanulmányozása előtt nem fogalmazódott meg a kutatóban a konduktív neveléssel, pedagógiai koncepciónkkal kapcsolatban? Árnyalhatja-e tovább szakmánkról alkotott tudásunkat egy képeinket érintő vizsgálat. 
A képelemzés lehetőségei a konduktív pedagógiában

\section{Képelemzés - egy lehetséges} mikroszintézis

Pető a maga korában, a negyvenes, ötvenes, hatvanas években mást tudott a mozgássérültekről és mást is közvetített róluk, mint kortársai. Folyamatosan és szisztematikusan dokumentálta és dokumentáltatta az intézetében folyó munkát. Számtalan fénykép, mozgókép őrzi a konduktív pedagógia első szakaszának emlékét. Ezeknek a képi forrásoknak több típusa létezik, érdemes őket elkülöníteni. Az első típusba tartoznak azok a mindennapi gyakorlatot segítő fotók, melyek bekerültek a személyes fejlődési lapokba. Rögzítették a neveltek bekerülési állapotát, nyomon követték a fejlődés lépcsőfokait, majd dokumentálták az elbocsátást is. A második csoportot képzik azok a fotók, melyek oktatási céllal készültek, ezek két altípusra oszthatók aszerint, hogy ki lesz a felhasználó. Eszerint az egyik altípusba tartoznak a konduktív pedagógia külföldi meghonosítását segítő fotók, melyek képi utasításokat tartalmaztak a konduktív munka megfelelő végzéséhez. A másik altípus a képzési céllal készült sorozatokat, filmeket tartalmazza, mely a konduktorképzés oktatási tartalmainak mélyebb megértését szolgálták.
Harmadik típusként jelenik meg az a képanyag, melynek feladata az intézet pedagógiai tevékenységének illusztrálása, eredményességünk bizonyítása. Megmutatja, hogy miként definiáljuk magunkat és mit tartunk fontosnak elmondani magunkról, megmutatni magunkból. A negyedik típusba az intézmény jeles napjain, ünnepein készült képi emlékek sorolhatók, ezeket alkalmi és hivatásos fotósoktól próbáljuk összegyűjteni. Jelen dolgozat az első típusból mutat meg egy jellegzetes felvételt.

A mindennapi praxist szolgáló képek közül egy felvételi, bekerülési fotót választottam. A felvételt az intézet hivatásos fotográfusa, Kőkúti Dénes készítette, és egy Pető által írt és munkatársai által szerkesztett kötet is tartalmazza (Hári és Ákos, 1971). A kép megtalálható a Pető András Főiskola irattárában (8111-47. sz. fotó) is, de a nem megfelelő állagvédelem miatt minősége sokat romlott, ezért a könyvben található példányt választottam az elemzéshez.

A fotón P. I.-t láthatjuk, a Pető Intézet neveltjét. Ez a kép az első intézeti kép róla. Rögzíti azt az (mozgás)állapotot, amelyben 1968 októberében élt.

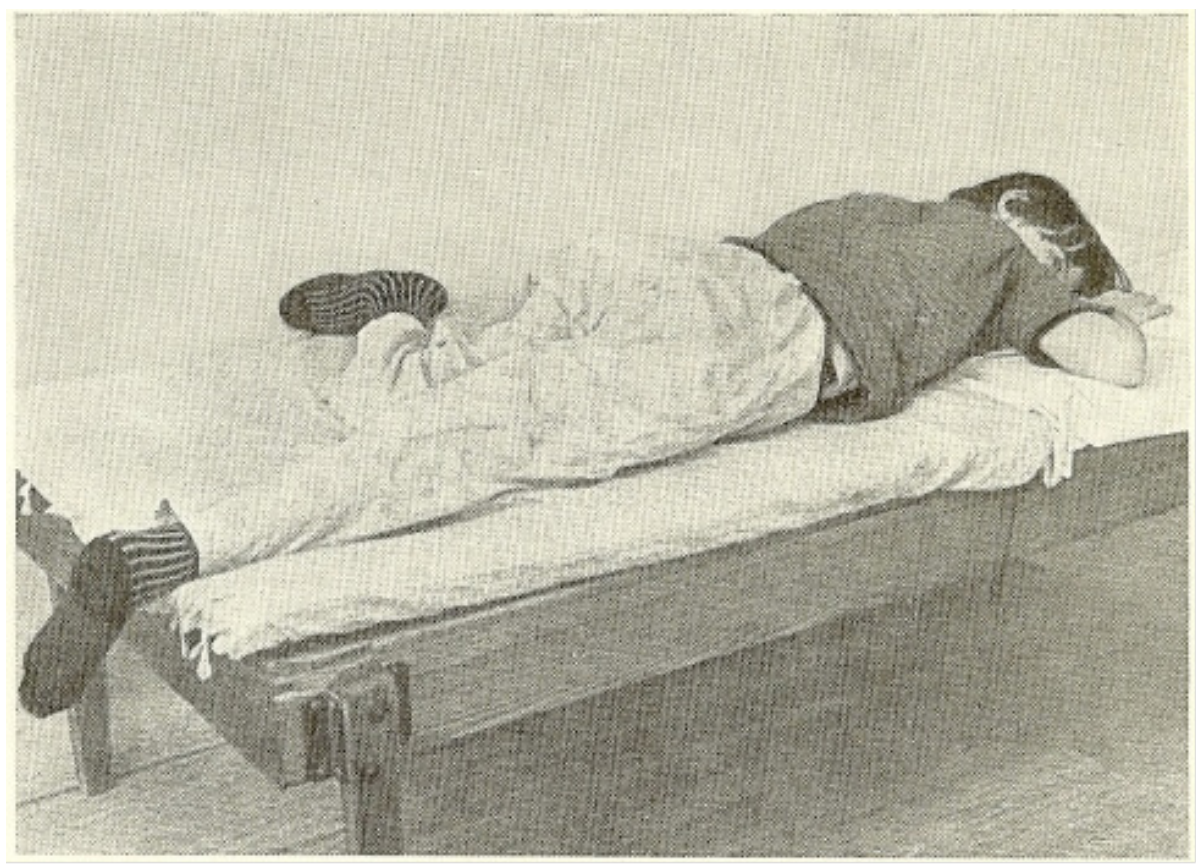

1. ábra: A Pető Intézet mindennapi praxisát illusztráló fénykép 
Kép 338. Idő, hely: 1968. október, Pető Intézet, Villányi úti épület, vizsgáló szoba

Technika: fekete-fehér

Készítette: Kőkúti Dénes (hivatásos fotográfus) Kiadást elrendelte: Művelődésügyi Miniszter Megjelenés helye: Hári Mária és Ákos Károly (1971): Konduktív Pedagógia. Tankönyvkiadó, Budapest.

Felhasználás: oktatási célra készült fénykép, dokumentációs célú fénykép

Az elemzés első szintje a preikonografikus leírás. Az elemzésnek ezen a szintjén csak az írható le, ami ténylegesen látszik a képen, amit bárki, aki ránéz a képre, meg tud állapítani, meg tud nevezni.

A kép világos. Világos háttér előtt egy emberalak (ezen a képen nem kódolható, hogy az illető férfi/nő, illetve milyen korú) fekszik hason egy ágyszerű alkalmatosságon, melyen világos tónusú textil látható. A kép geometriai középpontja a test hosszanti tengelyének közepe. A képet szinte teljesen elfoglalja az alak. A test teljes hosszában látszik, a jobb lábujjtól a jobb kéz kisujjáig. A fej a bal oldalán nyugszik, haja, jobb füle, jobb szeme, tehát a fej felső harmada látszik. A tekintet követhető, előre és kissé felfelé néz. Ha a szem csukva volna, felmerülhetne, hogy élö-e a test. Jobb kar hajlított helyzetben, könyök mellmagasságban, tenyér lefelé fordul. Jobb láb nyújtva, lábfej túllóg a fekvőfelületen. Bal térd hajlítva, a bal lábszár kifordulva a fekvőfelületre simul, a két comb összeér. Az egyén haja sötét, rövid ujjú felsőruházatot és hosszúszárú nadrágot visel, lábán zokni van.

$A z$ ikonográfiai leirás szakaszában már használható a képaláírás is, mint kiegészítő információ. A fénykép egy vizsgálati szituációban készült P. I. -ről, aki a kép készítésekor először járt a Pető Intézetben.

A kép aláírása:

P.I., született 1954. november. 8-án. Spasticus paraplegia. 1968. okt.: felvételkor hason fekve térdei szétvehetetlenül összeszorulnak. A térdeken decubitusok. A bal térd behajlik.

A képaláírásból kiolvasható, hogy mozgás- állapota igen rossz.

Feszes alsó végtagi bénulás miatt állni nem képes, mert bal lábát nem tudja kinyújtani és a talajra tenni, ott tartani. Felfekvései vannak a térdein, ez az állandó fekvő helyzet eredménye. A képaláírás elárulja a korát, a fotó tizennégy évesen örökíti meg. Neme azonban az aláírásból sem állapítható meg, a P.I. monogram ehhez nem elég információ.

A vizsgálati szituáció fontos eleme, hogy mindig spontán helyzetben készül, ami ebben az esetben a be nem avatkozást jelenti. Azt ábrázolja és mutatja a kép a majdani felhasználónak (hiszen dokumentációs fotó és oktatási információ is minden egyes kép az Intézetben), hogy ez a konduktív nevelést megelőző, kiinduló állapot. A kép fontos eleme az emberalak mellett az említett négylábú, lécezett felületű fekvőalkalmatosság, melynek szakneve: priccs. Kemény, fából készül, vastag fémcsapokkal és csavarokkal van összefogva. Stabil. Ez a konduktív pedagógia egyik alapeszköze, bútora, mely számos funkciót rejt magában. Lehet ágy, étkező- és tanulóasztal vagy eszköz járáshoz, ülve és fekve végzett feladatokhoz (ekkor azonban nincs rajta matrac, csak a kemény lécezett felület). A képen vizsgálóágyként funkcionál. Azonban a priccs mint szimbólum, mást is előhív. Anyagában a keménységet, jellegében a puritanizmust. A szó jelentése (nem a képen látható tárgy) pedig a börtönt juttathatja eszünkbe. És a nevelési intézmény, Pető intézete, totális intézmény, csakúgy, mint a börtön.

A vizsgálatkor viselt ruha saját, az intézet ugyanis napközben nem engedte hosszúszárú nadrág viselését, mert ezekben nem látszottak eléggé a végtagok helyzetei és mozgásai. Ezért az Intézet saját ruhakészlettel rendelkezett, amely egységessé és láthatóvá tette a nevelteket és megfelelő testrészeiket. A képen nincs egyéb tárgy, nem látható a vizsgálatot végző személy sem. A kép sivár, nincs a szobában semmi felesleges. Csak az ember és az állapot. Itt ez a fontos.

Az ikonográfiai interpretáció szintje a szándékokat is bemutatja (megrendelő, kép készítője), illetve különböző kontextusokban magyarázza is a képi információkat. A megrendelö és a fényképész célja egyértelműen a 
A képelemzés lehetőségei a konduktív pedagógiában

teljes test megmutatása. A testté, amely most így néz ki, de amely változni fog. Ha a fényképész lejjebb vagy feljebb, jobbra vagy balra mozdítja a kamerát, valami lemarad a képről, valami a testből. A modernizáció folyamán kezdték felfedezni a testet mint a hatalom tárgyát és célpontját. A testet kísérő megkülönböztetett figyelem jeleit könnyü megtalálni, hiszen a mindenkori hatalom századok óta befolyásolja, alakítja s készteti engedelmességre, behódolásra. A társadalom két irányból szemléli a testeket: anatómiai-metafizikai irányból, melynek diskurzusait orvosok és filozófusok folytatják, illetve technikai és politikai irányból, melynek lenyomatai a máig élő, katonai, iskolai, kórházi szabályzatok és működési keretek. Ez a két irány a „hasznos és megérthető testek" koncepciója (Foucault, 1990). A koncepció lényege a testek engedelmességében ragadható meg, mely kifejezést a (át)formálhatóság, a tökéletesíthetőség és ebből következően a hasznosíthatóság tölt meg tartalommal. Az alakíthatóság és a jobbá változtatás azonban feltételezi a testek részletes elemzését, megfigyelését, különböző szempontú dokumentálását, ellenőrzését. Az ötvenes, hatvanas évek pedagógiai kiadványaiban nemigen lelhetők fel sérült személyeket ábrázoló képek. Az „ami egészséges, az szép" gondolat az életreformmozgalmakon keresztül (Németh, 2013) beszivárgott az ötvenes-hatvanas évek kommunista/szocialista ideológiájába, ez a korabeli képi kiadványokon jól tetten érhető. Pető azonban sérült megtestesülésekkel találkozik. Feladata a gyógyultság elérése, amely elmélete szerint független az anatómiai, látható gyógyulástól. Az elemzett képen a test tehetetlen és kiszolgáltatott, kifacsarodott. Az egyetlen élő dolog a tekintet, a kép egy kicsiny részlete. De mégis az az egy szem, az a tekintet nagyon erösen vonz, belenézésre késztet, ezzel válik a kép tényleges, tartalmi középpontjává. Teljes összhangot mutat a test helyzetével, elzárkózottság, elzártság, befelé fordulás olvasható ki belőle. Az egyén nincs a képben, kívül helyezi magát a helyzeten. Így védekezik. Ezt az érzetet erősíti az arc elé húzott kar is, amelyet nem indokol a mozgásállapot súlyossága, hiszen a karok jól funkcionálnak paraplégia esetén.
Az elemzés utolsó szakaszában, az ikonológiai interpretációban a szimbólumok megfejtése kap fö hangsúlyt, tulajdonképpen egy tág kontextusban történő, ideológiák mentén is zajló diskurzus jön létre a kép és a kutató között. Pető elmélete, elvárása szerint fontos, hogy a felvételi fotón ott legyen, látszódjon a teljes test, de a teljes test jelenléte szimbolizálja a teljes, szétszabdalhatatlan személyiséget, aki ha fejlődik, minden porcikájában, minden képességében változik, mert az egyén mint organizmus, nem más, mint öszszefüggések rendszere, amelyben ha egy valami változik, akkor változik minden más is. A változást, azonban az egyénnek magának kell elérnie, itt „csak” megkapja hozzá az éppen megfelelő mértékű segítséget. Ezért a képen egyedül lenni azt is jelenti: magam vagyok, én vagyok maga a cél és maga a feladat. Az egyedül levés viszont kizárólag a tudatra érvényes, hiszen Pető egyik alapelve, hogy csakis csoportban dolgozva, személyközi kapcsolatok rendszerében érhetőek el valós és tartós eredmények az egyénre nézve. A felvételi fotón látható magányosság tehát átmeneti állapot, ez a tranzit. Tranzit egy speciális, nem megszokott, kicsit fura világba, ahol az egész rendszer másként müködik, mint a többi, sérültekkel (akkori szóhasználat szerint nyomorékokkal) foglalkozó intézményben. Pető világa szembement kortársai világával, az intézet kicsit olyan volt, mint egy kísérleti helyszín, ahol bizonyítani fogja az igazát, mert tudta, hogy igaza van, és olyan, hogy „képezhetetlen és fejleszthetetlen" egyszerűen nem létezik.

\section{Összegzés}

Pető András nevelési-munkaszervezési koncepciójának fontos eleme volt egy olyan közösség és tér létrehozása, ahol egy magasabb rendủ célért lehet és kell munkálkodni. Több fronton küzdött azért, hogy kompromisszumok nélkül tudjon teremteni egy helyet, ahol a lélekre és érzelemre építve képes müködtetni egy olyan rendszert, amelyben a résztvevők szenvedélye, célorientáltsága, tudatossága elvezet ahhoz, hogy a nevelt a valódi akarata, aktivitása segítségével élhesse meg 
saját egészlegességét. A medicina és a pedagógia összekapcsolása, a „nyomorék” emberként tisztelete, az emberben rejlő képességek és lehetőségek meglétében való bizonyosság, a cél, az Ügy, mindennél fontosabb volt Pető számára. 1967-ben bekövetkezett halálával lezárult a konduktív pedagógia első, talán legfontosabb szakasza. Ekkorra forrott ki és szerveződött igazi egységgé az a speciális gondolatrendszer, amely a konduktív nevelés lényegét, a nevelési folyamathoz és benne a nevelődőhöz való modern, a szokásostól nagymértékben eltérő közelítést jelentette. Ennek lenyomatai ott rejtőznek abban a részletes, szisztematikus dokumentációs bázisban, amely ránk maradt. Vizuális emlékeink kutatása ugyan még épp, hogy elkezdődött, de már látható, hogy a képi történetek segítenek a konduktív pedagógiáról, annak lényegéről való gondolkodásban. A konduktív pedagógia képeit vizsgálva elmondható, hogy alapvetően alkalmazható rá a képelemzés módszere. Itt is érvényes, hogy a megfejtett szimbólumok segítségével egy fotó is képes bemutatni akár egy teljes eszmerendszert, ha megfelelő háttértudásunk van az adott korról és annak kulturális-társadalmi jellegzetességeiről, illetve a konkrét kutatási téma tényanyagáról.

A konduktív pedagógia képanyagát kutatva a későbbiekben talán az jelenti majd a nehézséget, hogy a közvetlen emberi kommunikáció szabályszerűségei mennyiben rekonstruálhatók olyan képekről, melyeken az emberi test, a mozdulatok, az arcizomzat nem úgy müködik, ahogyan azt a „tulajdonosa" szeretné. Ez azonban már egy következő kutatási fázis témája lesz.

\section{Felhasznált irodalom}

Aries, Philippe (1987): Gyermek, család, halál. Gondolat, Budapest.

Barthes, Roland (1985): Világoskamra. Jegyzetek a fotográfiáról. Európa Kiadó, Budapest.

Báthory Zoltán és Falus Iván (2001): Tanulmányok a neveléstudományok köréböl. Budapest, Osiris.

Boehm, Gottfried (1998): A képleírás. A kép és nyelv határairól. In: Thomka Beáta (szerk.)
Narratívák I. Képleirás, képi elbeszélés. Kijárat Kiadó, Budapest, 9-37.

Buckingham, David (2002): A gyermekkor halála után. Helikon, Budapest.

Buda Béla (1974): A közvetlen emberi kommunikáció szabályszerüségei. Animula, Budapest.

Falus Iván (2000, szerk.): Bevezetés a pedagógiai kutatás módszereibe. Műszaki Könyvkiadó, Budapest.

Endrődy-Nagy Orsolya (2015): A reneszánsz gyermekképe. A gyermekkép reneszánsza 1455-1517 között Európában. Ikonográfiai elemzés. ELTE Eötvös Kiadó, Budapest.

Foucault, Michel (1990): Felügyelet és büntetés. Gondolat Kiadó, Budapest.

Géczi János (2008): Ikonológia-ikonográfia mint a történeti pedagógia segédtudománya. In: Pukánszky Béla (szerk.) A neveléstörténet-írás új útjai. Gondolat Kiadó, Budapest, 180-193.

Géczi János (2010): A szocialista nevelésügy két képi hangsúlya. Iskolakultúra, 20. 1. sz., 79-91.

Géczi János (2010): Sajtó kép, neveléstörténet. Tanulmányok. Iskolakultúra-könyvek 38., Gondolat Kiadó, Veszprém - Budapest.

Géczi János (2012): A történeti pedagógia segédtudománya: Ikonológia-ikonográfia. Létünk, 7. 4. sz., 103-119.

URL: epa.oszk.hu/00900/00997/00023/pdf/ EPA00997_Letunk_2012_4_103_119.pdf

Goffmann, Erwing (1981): Képi keretek. In: Goffmann, Erwing $A$ hétköznapi élet szociálpszichológiája. Gondolat Kiadó, Budapest, 547-612.

Golnhofer Erzsébet és Szabolcs Éva (2005): Gyermekkor: nézőpontok, narratívák. Eötvös József Könyvkiadó, Budapest.

Golnhofer Erzsébet és Szabolcs Éva (1999): A gyermekkor kutatása új megközelítésben. Mühely, 22. 5-6. sz., 175-178.

Hári Mária, Horváth Júlia, Kozma Ildikó és Kőkúti Márta (1991): A konduktív pedagógiai rendszer hatékony müködésének alapelvei és gyakorlata. Nemzetközi Pető Intézet, Budapest.

Hári Mária és Ákos Károly (1971): Konduktív pedagógia. Tankönyvkiadó Vállalat, Budapest.

Karácsony András (1995): Bevezetés a tudásszociológiába. Gondolat Kiadó, Budapest.

Kelemen Elemér (1997): Ezeréves a magyar iskola. Beszámoló az iskolatörténeti évforduló rendezvényeiről, eseményeiről. Új Pedagógiai Szemle, 47. 3. sz., 81-93. 
A képelemzés lehetőségei a konduktív pedagógiában

Kéri Katalin (2001): Bevezetés a neveléstörténeti kutatások módszertanába. Budapest, Műszaki Könyvkiadó.

Kéri Katalin (2003): Gyermekkép Magyarországon az 1950-es évek első felében. In: Pukánszky Béla (szerk.): Két évszázad gyermekei. Budapest, Eötvös József Könyvkiadó, 229-245.

Kluge, Norbert (2003): A gyermeklét antropológiája. Animula, Budapest.

Kunt Ernő (1995): Fotoantropológia. Fényképezés és kultúrakutatás. Arkádiusz, Miskolc-Budapest.

Mitchell, W. J. T. (2008): A képek politikája. JATE. Press, Szeged.

Mikonya György (2006): Pedagógiai életképek az 1945 utáni magyar nevelés történetéből. In: Szabolcs Éva (szerk.): Pedagógiai és politika a XX. század második felében Magyarországon. Eötvös Kiadó, Budapest, 59-114.

Németh András és Szabolcs Éva (2001): A neveléstörténeti kutatások föbb nemzetközi tendenciái, új kutatási módszerei és eredménye. In: Báthory Zoltán és Falus Iván (szerk.): Tanulmányok a neveléstudományok köréből. Osiris, Budapest.

Németh András és Pukánszky Béla (2004): A pedagógia problématörténete. Gondolat Kiadó, Budapest.

Németh András és Pirka Veronika (2013, szerk.): Az életreform és reformpedagógia - recepciós és intézményesülési folyamatok a 20. század első felében. Gondolat Kiadó, Budapest.

Panofsky, Erwin (1984): Ikonográfia és ikonológia: bevezetés a reneszánsz művészet tanulmányozásába. In: Panofsky, Erwin. Jelentés a vizuális müvészetekben. Gondolat Kiadó, Budapest, 284-307.

Pilarzcyk, Ulrike és Mietzner. Ulrike. (2010): A képtudomány módszerei a neveléstudományi és társadalomtudományi kutatásban. Iskolakultúra, 20. 5-6. sz., 1-20.

Prout, A. (2004): The Future of Childhood. Routledge, London.

Pukánszky Béla (2004): Fejezetek a gyermekkor és a családi nevelés történetéből. In: Németh András és Pukánszky Béla $A$ pedagógia problématörténete. Gondolat Kiadó, Budapest, 259-330.

Pukánszky Béla (2000, szerk.): A gyermek évszázada. Osiris Kiadó, Budapest.

Pukánszky Béla (2001): A gyermekkor története. Müszaki Kiadó, Budapest.

Reismann Mariann (1956): Gyermekfényképezés. Fotosorozat 8. Műszaki Könyvkiadó, Budapest.
Sántha Kálmán (2006): Mintavétel a kvalitativ pedagógiai kutatásban. Kutatás-módszertani Kiskönyvtár, Gondolat Kiadó, Budapest.

Somogyvári Lajos (2012): Közelítések a portrék és az egyszereplős képek jelenségéhez a magyar pedagógiai szaksajtóban (1960-1970). I. rész. Iskolakultúra, 22. 5. sz., 56-75.

Somogyvári Lajos (2012): Közelítések a portrék és az egyszereplős képek jelenségéhez a magyar pedagógiai szaksajtóban (1960-1970). II. rész. Iskolakultúra, 22. 6. sz., 14-37.

Somogyvári Lajos (2015): Ikonográfia a neveléstörténet-írásban. Pedagógiai életképek a hatvanas évekből. Gondolat Kiadó, Budapest.

Szabolcs Éva (2001): Kvalitatív kutatási metodológia a pedagógiában. Műszaki Könyvkiadó, Budapest.

Szabolcs Éva (2003): Gyermekkortörténet: új elméleti megfontolások. In: Pukánszky Béla (szerk.) Két évszázad gyermekei. Eötvös József Könyvkiadó, Budapest, 9-17.

Szabolcs Éva (2004): „Narratívák a gyermekkorról. Iskolakultúra, 14. 3. sz., 27-31.

Sztompka, Piotr (2009): Vizuiális szociológia. Gondolat Kiadó, Budapest.

TámbaRenátó(2015):Osztálytermifényképekakalksburgi jezsuita gimnáziumból. In: Kaposi Angéla és Ugrai János (szerk.) Elitek nevelése és oktatása. Esetek és összefüggések a 18-20. századból. Új Mandátum Könyvkiadó, Budapest, 71-87.

Thomka Beáta (1998): Képi időszerkezetek. In: Thomka Beáta (szerk.) Képelemzés. Narratívák 1. Kijárat Kiadó, Budapest, 7-19.

Vajda Zsuzsanna (1997): Elveszett gyermekkor. 2000, 9. 11. sz., 46-48.

Winn, Marie (1990): Gyermekek gyermekkor nélkül. Gondolat Kiadó, Budapest. 


\section{Possibilities of Picture Analysis in Conductive Pedagogy}

In the 1940s, '50s and '60s András Petö knew and transmitted about persons with motor disabilities different knowledge and perspectives than contemporaries would. He continuously and systematically documented the Institute's day-to-day activities. Therefore, innumerable photos and films keep alive the memory of the first stage of conductive education. Although the examination of our visual heritage has only just started, we can already see that visual stories make a great contribution to our thinking about the essence of conductive education. Studying the pictures of conductive education, it is clear that the method of pictorial analysis is a good way of analysing them. With the help of symbols decoded, one single photo is able to reflect the complete philosophical system, if we have the adequate background knowledge of the age and its socio-cultural features and also about the facts of the given research theme.

Keywords: childhood, conductive pedagogy, persons with motor disabilities, visual sources, iconography-iconology

Földesi Renáta (2017): A képelemzés lehetőségei a konduktív pedagógiában. Gyermeknevelés, 5. 1. sz., $143-154$ 